\title{
PENGARUH PENEBANGAN HUTAN TANAMAN Eucalyptus pellita F.Muell TERHADAP PENINGKATAN ALIRAN SUNGAI DAN SEDIMEN
}

\author{
Effect of Harvesting of Eucalyptus pellita F.Muell Forest Stand in Increasing \\ River Flow and Sediment
}

\begin{abstract}
Agung Budi Supangat ${ }^{1}$, Putu Sudira ${ }^{2}$, Haryono Supriyo ${ }^{3}$ dan/and Erny Poedjirahajoe ${ }^{4}$
${ }^{1}$ Balai Penelitian dan Pengembangan Teknologi Pengelolaan DAS, Jl. Jend. A. Yani - Pabelan, Kartasura Po Box 295 Surakarta 57102, Jawa Tengah, Indonesia, Telp: (0271) 716709.

${ }^{2}$ Jurusan Teknik Pertanian, Fakultas Teknologi Pertanian Universitas Gadjah Mada, Jl. Flora No. 1, Bulaksumur Yogyakarta 55281, Daerah Istimewa Yogyakarta, Indonesia

${ }^{3}$ Bagian Silvikultur, Fakultas Kehutanan Universitas Gadjah Mada,

Jl. Agro, Bulaksumur, Yogyakarta 55281, Daerah Istimewa Yogyakarta, Indonesia

${ }^{4}$ Bagian Konservasi Sumberdaya Hutan, Fakultas Kehutanan Universitas Gadjah Mada,

Jl. Agro, Bulaksumur, Yogyakarta 55281, Daerah Istimewa Yogyakarta, Indonesia

Email :maz_goenk@yahoo.com; psudira@yahoo.com; haryonosupriyo@yahoo.com; er_pjr@yahoo.com
\end{abstract}

Tanggal diterima : 8 Juni 2015; Tanggal direvisi : 14 November 2016 Tanggal disetujui :

\begin{abstract}
The study aimed to determine the effect of harvesting on the river flow and sedimentation. The research was carried out in Eucaliptus pellita plantations forest in Perawang District, Riau Province. The catchment water balance method was used by using the micro-catchment as observation unit. The research concluded that clear cutting system led triver flow increment by $142.6 \%$ in the period 0 to 8 months after harvesting, from 45.5 mm. month ${ }^{-1}$ (before logging) to 110.5 mm.month ${ }^{-1}$ (after logging). Monthly runoff coefficient increased by $95.3 \%$ from $34.0 \%$ to $66.0 \%$. I Clear-cutting also increased monthly sediment yield by $788.7 \%$ from 0.18 ton.ha h $^{-1}$.month ${ }^{-1}$ (before logging) to 1.57 ton.ha' month $^{-1}$ (after logging).
\end{abstract}

Keywords: Clear cutting, E. pellita, plantation forest, river flow and sediment

\begin{abstract}
ABSTRAK
Tujuan penelitian ini adalah untuk mengetahui pengaruh penebangan hutan tanaman terhadap aliran sungai dan sedimentasi. Penelitian dilaksanakan di kawasan hutan tanaman E. pellita di Perawang, Propinsi Riau. Teknik yang digunakan adalah metode pengukuran neraca air dengan menggunakan satuan pengamatan berupa mikro DAS. Hasil penelitian menunjukkan bahwa akibat penebangan dengan sistem tebang habis telah menyebabkan peningkatan aliran sungai sebesar $142,6 \%$ pada periode 0 sampai 8 bulan setelah penebangan dari rata-rata $45,5 \mathrm{~mm}$ per bulan (sebelum penebangan) menjadi $110,5 \mathrm{~mm}$ per bulan (setelah penebangan) serta meningkatkan koefisien limpasan permukaan bulanan sebesar $95,3 \%$, yakni dari $34,0 \%$ menjadi $66,0 \%$. Kegiatan penebangan menyebabkan peningkatan sedimen bulanan sebesar $788,7 \%$ dari 0,18 ton per ha per bulan sebelum penebangan menjadi 1,57 ton per ha per bulan setelah penebangan.
\end{abstract}

Kata kunci: E. pellita, debit, hutan tanaman, sedimen dan tebang habis

\section{PENDAHULUAN}

Hutan sering diyakini menjadi tutupan lahan yang paling baik dalam menjaga fungsi hidroorologis daerah aliran sungai (DAS). Hutan beserta komponen ekosistemnya merupakan sistem pengatus yang berfungsi efektif dalam melindungi permukaan tanah dari energi kinetis hujan, menyimpan dan menahan lebihan hujan agar tetap berada di tanah lapisan permukaan, mengendalikan laju limpasan permukaan (run off) maupun melindungi tanah dari bahaya erosi (Fukuyama et al., 2010; Alidoust, Zahedi, \& Pornasrollah, 2012; Neris, Tejedor, Rodríquez, Fuentes, \& Jiménez, 2013; Cao, Liang, Wang, \& $\mathrm{Lu}, 2015)$. Dibandingkan penutupan jenis vegetasi yang lain, hutan dapat menghasilkan debit banjir pada tingkat yang rendah dan 
meningkatkan stabilitas tanah, disebabkan karena tingginya kapasitas infiltrasi, adanya perlindungan dari tutupan tajuk pohon, tingginya konsumsi terhadap air tanah dan tingginya kekuatan regang dari perakaran pohon (Hofer, 2003; Mohammad \& Adam, 2010; Alidoust et al., 2012; Neris et al., 2013).

Namun demikian, banyak yang mempertanyakan apakah hutan tanaman juga dapat berfungsi hidrorologis, seperti hutan alam. Secara struktural, komposisi dan strata vegetasi penyusun hutan tanaman berbeda dengan hutan alam. Demikian juga, sistem pengelolaan hutan yang dilakukan sangat berbeda. Pada hutan tanaman terdapat fase-fase dimana kondisi hutan rawan mengalami degradasi, seperti pada saat pemanenan (tebang habis), penyiapan lahan serta tanaman muda. Pada fase-fase tersebut disinyalir sebagai sumber terjadinya degradasi lahan, terkait dengan tingginya tingkat erosi, limpasan permukaan dan sedimentasi (Tian et al., 2008; Löfgren, Ring, von Bromssen, Sørensen, \& Högbom, 2009; Suarez, Soto, Perez, \& Fierros, 2011).

Perubahan dari hutan alam maupun sekunder menjadi hutan tanaman serta adanya aktivitas tindakan silvikultur, seperti pemanenan merupakan gangguan berupa konversi tutupan hutan, sehingga menjadi lebih terbuka. Telah banyak hasil-hasil penelitian terkait hubungan pengelolaan hutan terhadap karakteristik hidrologi DAS. Konversi hutan menjadi non hutan atau pengurangan luas tutupan hutan telah menyebabkan terganggunya fungsi hidrologis, diantaranya dapat meningkatkan hasil air untuk kurun waktu tertentu (Zhao, Zhang, \& Xu, 2009; Sørensen et al., 2009; Nobrega, Souza, \& Souza, 2010; Zegree, 2011; Khanal \& Parajuli, 2013; Shamsuddin, Yusop, \& Noguchi, 2014), meningkatkan sedimentasi di badan air (Brown, 2010; Khanal \& Parajuli, 2013), menurunkan kualitas air sungai (Feller, 2005; Löfgren et al., 2009; Palmer, 2011) serta mempengaruhi karakteristik hidrograf aliran (Wenjie, Wenyao, Hongjian, Wenping, \& Hongmei, 2011; Kuras, Alila, \& Weiler, 2012; Suryatmojo, Masamitsu, Kosugi, \& Mizuyama, 2013).

Demikian juga, keberadaan hutan tanaman Eucalyptus pellita yang dikembangkan di Indonesia sebagai hutan penghasil pulp, perlu diketahui karakteristik hidrologisnya. E. pellita di pulau Sumatera khususnya di Provinsi Riau, telah dikembangkan di lahan hutan tanaman industri (HTI) dan telah mencapai rotasi keempat. Penanaman dalam skala luas serta kegiatan silvikultur yang diterapkan pada jenis tanaman cepat tumbuh (fast growing species) ini disinyalir berdampak pada berubahnya fungsi hidrologi DAS.

Penelitian ini bertujuan untuk mengetahui pengaruh penebangan hutan tanaman E. pellita terhadap aliran sungai dan sedimentasi. Selain sebagai sumbangan dalam ilmu pengetahuan bidang hidrologi hutan, informasi yang diperoleh dapat mendukung perencanaan teknik pengelolaan lingkungan hutan tanaman dalam rangka meminimalkan dampak negatif dari pengelolaan hutan tanaman yang dilakukan.

\section{METODOLOGI}

\section{A. Lokasi dan Waktu Penelitian}

Penelitian dilakukan di kawasan hutan tanaman E. pellita di areal kerja HPHTI PT. Arara abadi di Distrik Rasau Kuning, Kabupaten Siak, Propinsi Riau. Lokasi mikro DAS pengamatan berada pada petak 175-B (Gambar 1) dengan ukuran luas 4,62 ha serta berisi tanaman E. pellita yang ditanam pada bulan Mei 2006 dengan jarak tanam $2 \mathrm{~m} \times 3 \mathrm{~m}$. Letak geografis lokasi penelitian berada pada $00^{\circ} 41,656^{\prime}-00^{\circ} 45,361^{\prime} \mathrm{LU}$ dan $101^{\circ} 34,657^{\prime}-101^{\circ} 36,384^{\prime} \mathrm{BT}$, dengan ketinggian tempat berkisar antara 39-74 $\mathrm{m} \mathrm{dpl}$.

Pengamatan iklim mikro di lokasi penelitian menunjukkan tipe iklim A (Schmidt Ferguson), dengan curah hujan tahunan berkisar 1.937-3.484 $\mathrm{mm}$ (rata-rata $2.456 \mathrm{~mm}$ per tahun). Suhu udara harian rata-rata sebesar $27,7^{\circ} \mathrm{C}$, dengan rata-rata maksimum $29,3^{\circ} \mathrm{C}$ dan rata-rata minimum $26,4^{\circ} \mathrm{C}$ sedangkan kelembaban udara harian ratarata sebesar $68,7 \%$, dengan rata-rata maksimum $75,1 \%$ dan rata-rata minimum $63,0 \%$ (Supangat, Junaedi, Kosasih \& Irwan, 2010). Jenis tanah di lokasi penelitian adalah Ultisols (podsolik merah kuning), dengan kelas tekstur tanah geluh pasiran (sandy loam) sampai geluh lempung pasiran (sandy clay loam). Jenis tanah ini terbentuk dari bahan induk batuan sedimen pasir yang bersifat masam dan termasuk tanah yang peka terhadap erosi permukaan (Suharta \& Prasetyo, 2008).

Penelitian dilaksanakan pada tahun 2012. Penebangan tanaman E. pellita dengan sistem tebang habis di dalam mikro DAS dilakukan pada bulan Maret 2012, sehingga pengamatan tata air dilakukan sebelum dan setelah aktivitas penebangan. 


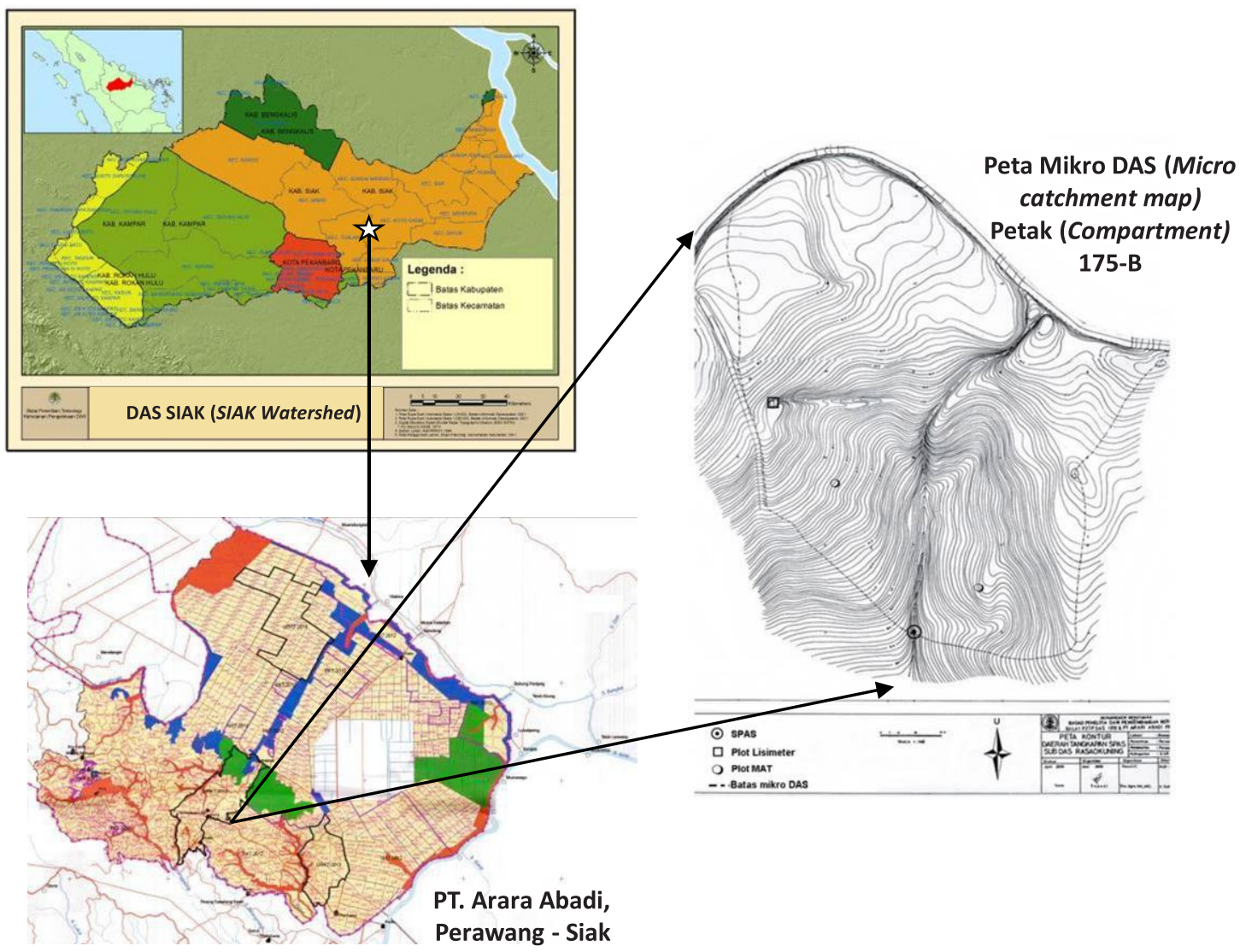

Gambar (Figure) 1. Lokasi penelitian (Research location)

\section{B. Bahan dan Alat}

Bahan yang digunakan adalah lahan hutan tanaman E. pellita yang berada pada satuan mikro DAS yang dilengkapi sarana pemantauan tinggi muka air di bagian outletnya. Adapun peralatan penelitian meliputi alat pengukur curah hujan, alat pengukur tinggi muka air (TMA) sungai secara otomatis tipe HOBO U20 Water Level Data Recorder, suspended sediment sampler serta alat tulis kantor.

\section{Pengumpulan Data}

Pengamatan hidrologi sungai dilakukan dengan menggunakan satuan mikro DAS berukuran 4,62 ha dan dipilih lokasi yang pada sungai utamanya terdapat aliran sepanjang tahun. Data yang dikumpulkan adalah data curah hujan harian dari alat ukur curah hujan, data TMA sungai yang terekam melalui water level logger serta pengambilan sampel sedimen yang dilakukan setiap hari.

Pengukuran debit air yang keluar dari sistem mikro DAS hutan tanaman E. pellita diukur melalui pengamatan secara otomatis terhadap TMA (H) sungai pada outlet mikro DAS. Model penampang melintang sungai digunakan modifikasi gabungan model Cipolletti dan $\mathrm{V}$ notch weir sudut $90^{\circ}$. Pada TMA 0-20 cm air melimpah melalui $V$-notch weir dan pada TMA $21 \mathrm{~cm}$ ke atas air sungai melimpah melalui Cipolletti weir. Pengukuran sedimen terangkut dilakukan dengan pengambilan sampel air yang dilakukan setiap hari dan pada berbagai ketinggian muka air sungai. Sampel air kemudian dibawa ke laboratorium untuk dilakukan analisis kandungan sedimennya (CS).

\section{Pengolahan dan Analisis Data}

Besarnya debit air dihitung dengan menggunakan persamaan regresi yang terbangun, yaitu hubungan antara TMA $(\mathrm{H})$ dan debit (Q) atau stage-discharge rating curve, yaitu: $\mathrm{Q}=\mathrm{a}$ $\mathrm{H}^{\mathrm{b}}$. Berdasarkan pengukuran yang telah dilakukan oleh Supangat (2013), diperoleh dua persamaan debit, yaitu model penampang $V$ notch weir $(\mathrm{H} \leq 20 \mathrm{~cm})$ dan penampang Cipolletti $(\mathrm{H}>20 \mathrm{~cm})$ sebagai berikut : 


\section{B. Bahan dan Alat}

Bahan yang digunakan adalah lahan hutan tanaman E. pellita yang berada pada satuan mikro DAS yang dilengkapi sarana pemantauan tinggi muka air di bagian outletnya. Adapun peralatan penelitian meliputi alat pengukur curah hujan, alat pengukur tinggi muka air (TMA) sungai secara otomatis tipe HOBO U20 Water Level Data Recorder, suspended sediment sampler serta alat tulis kantor.

\section{Pengumpulan Data}

Pengamatan hidrologi sungai dilakukan dengan menggunakan satuan mikro DAS berukuran 4,62 ha dan dipilih lokasi yang pada sungai utamanya terdapat aliran sepanjang tahun. Data yang dikumpulkan adalah data curah hujan harian dari alat ukur curah hujan, data TMA sungai yang terekam melalui water level logger serta pengambilan sampel sedimen yang dilakukan setiap hari.

Pengukuran debit air yang keluar dari sistem mikro DAS hutan tanaman E. pellita diukur melalui pengamatan secara otomatis terhadap TMA (H) sungai pada outlet mikro DAS. Model penampang melintang sungai digunakan modifikasi gabungan model Cipolletti dan $\mathrm{V}$ notch weir sudut $90^{\circ}$. Pada TMA 0-20 cm air melimpah melalui $V$-notch weir dan pada TMA $21 \mathrm{~cm}$ ke atas air sungai melimpah melalui Cipolletti weir. Pengukuran sedimen terangkut dilakukan dengan pengambilan sampel air yang dilakukan setiap hari dan pada berbagai ketinggian muka air sungai. Sampel air kemudian dibawa ke laboratorium untuk dilakukan analisis kandungan sedimennya (CS).

\section{Pengolahan dan Analisis Data}

Tabel(Table) 1. Hasil air dan hasil sedimen bulanan di hutan tanaman E. pellita tahun 2012 (Monthly water yield and sediment yield at E. pellita plantation forest, year 2012)

\begin{tabular}{|c|c|c|c|c|c|c|c|c|c|c|c|c|}
\hline \multirow{2}{*}{$\begin{array}{c}\text { Parameter } \\
\text { Hidrologi } \\
\text { (Hydrological } \\
\text { parameters) }\end{array}$} & \multicolumn{12}{|c|}{ Bulan (Month) } \\
\hline & Jan & Feb & Mar & Apr & Mei & Jun & Jul & Agt & Sept & Okt & Nop & Des \\
\hline $\begin{array}{l}\text { Curah hujan } \\
\text { (Rainfall, mm) }\end{array}$ & 183 & 98 & 222 & 206 & 154 & 34 & 127 & 97 & 196 & 168 & 524 & 210 \\
\hline $\begin{array}{l}\text { Total limpasan } \\
\text { (Total run off, mm) }\end{array}$ & 53,4 & 37,7 & 48,7 & 73,8 & 95,9 & 43,3 & 94,2 & 63,5 & 109,9 & 104,6 & 293,8 & 115,4 \\
\hline $\begin{array}{l}\text { Koef. Limpasan } \\
\text { (Run off coeff.) }\end{array}$ & 0,29 & 0,38 & 0,22 & 0,36 & 0,62 & 1,27 & 0,74 & 0,65 & 0,56 & 0,62 & 0,56 & 0,55 \\
\hline $\begin{array}{l}\text { Sedimen } \\
\text { (Sediment, ton per ha) }\end{array}$ & 0,25 & 0,10 & 0,19 & 0,70 & 1,07 & 0,16 & 1,13 & 0,41 & 2,01 & 1,10 & 6,57 & 0,99 \\
\hline
\end{tabular}


$\mathrm{QS}=52,023 \mathrm{Q}^{1,7202} \quad$ (kg per detik)
$\mathrm{n}=45 ; \mathrm{r}^{2}=0,943$

Tahun 2012 (Tanaman E. pellita umur 0-1 tahun, setelah penebangan):

$\mathrm{QS}=71,418 \mathrm{Q}^{1,2313} \quad$ (kg per detik)
$\mathrm{n}=88 ; \mathrm{r}^{2}=0,969$

\section{HASIL DAN PEMBAHASAN}

\section{A. Hasil Penelitian}

Kondisi karakteristik hidrologi pada tahun 2012 menggambarkan kondisi pada saat atau fase tanaman tua (akhir daur), pada saat pemanenan (bulan Maret), pada fase pasca pemanenan dan penyiapan lahan (bulan April) serta pada fase tanaman muda (bulan Mei sampai Desember). Hasil pemantauan hasil air dan hasil sedimen bulanan tahun 2012 disajikan pada Tabel 1.

Berdasarkan data dari Tabel 1 di atas, diketahui bahwa dengan total curah hujan tahun 2012 sebesar $2.219 \mathrm{~mm}$ menghasilkan debit air tahunan sebesar $0,604 \mathrm{~m}^{3}$ per detik atau setara dengan limpasan atau aliran permukaan sebesar $1.134,1 \mathrm{~mm}$. Dengan demikian, nilai koefisien aliran permukaan tahunan diperoleh sebesar 0,51 , yang berarti sebesar $51,0 \%$ dari air hujan menjadi aliran permukaan, selebihnya berupa air intersepsi yang dikembalikan ke atmosfer serta sebagian meresap ke dalam tanah melalui proses infiltrasi. Hasil sedimen pada tahun 2012 sebesar 14,66 ton per ha, mengalami kenaikan dibandingkan tahun sebelumnya (2011) sebesar 1,42 ton per ha, yaitu pada saat tanaman E. pellita berumur 5 tahun (Supangat, 2013).

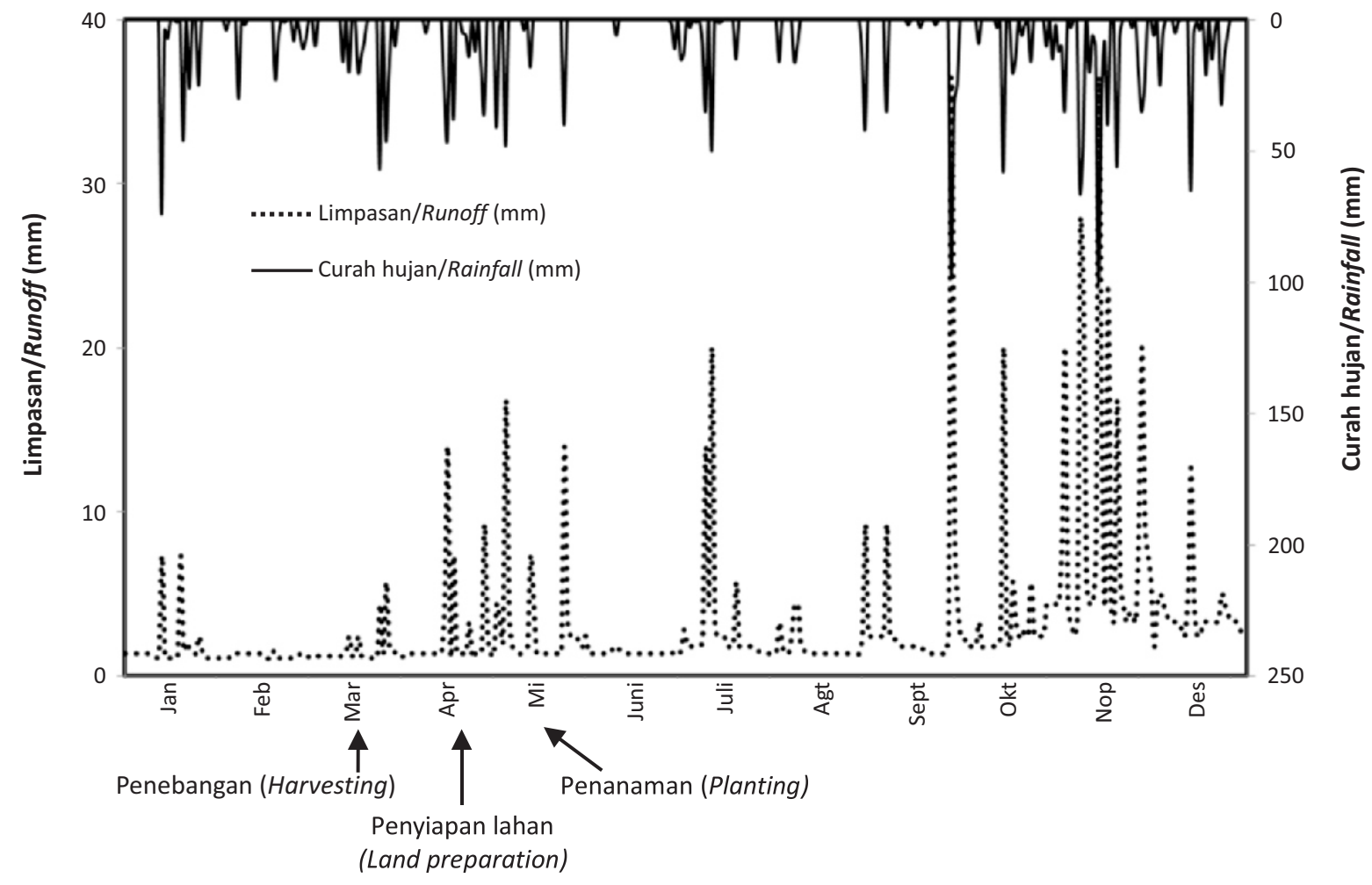

Gambar (Figure)2. Grafik hujan dan limpasan harian tahun 2012 (Graph of daily rainfall and run off for year 2012) 


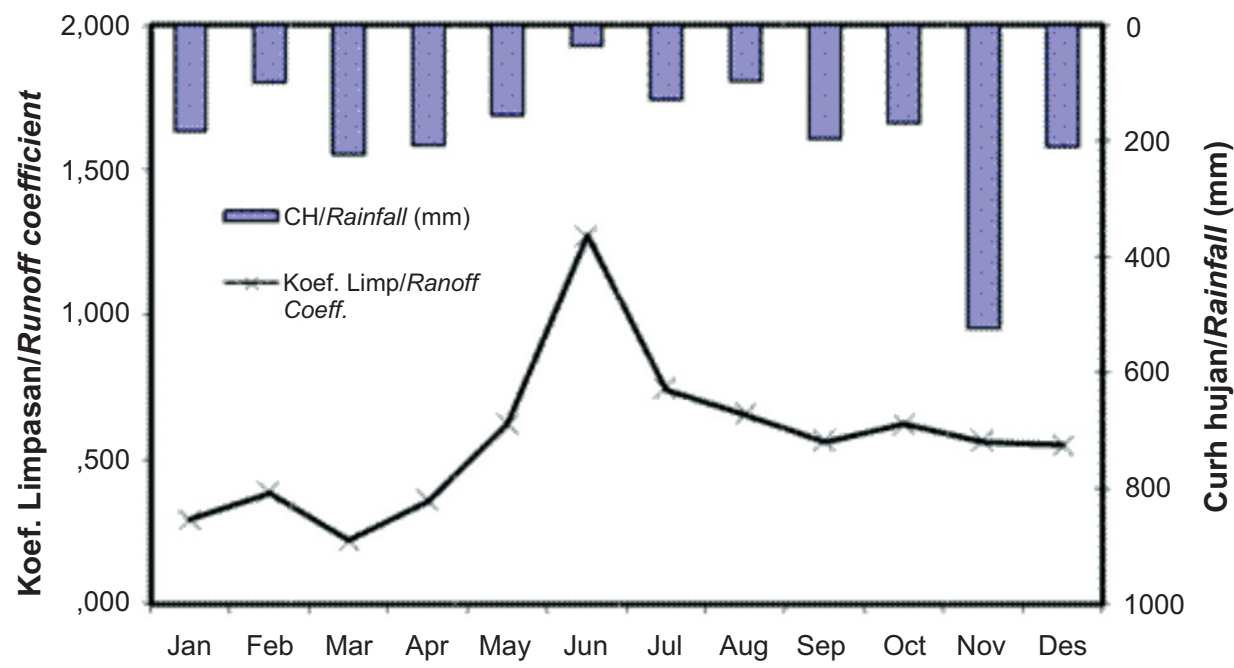

Gambar(Figure) 3. Grafik hujan dan koefisien limpasan bulanan tahun 2012 (Graph of monthly rainfall and run off coefficient for year 2012)

Hasil penelitian ini sejalan dengan fenomena yang ditemukan oleh penelitian-penelitian sebelumnya. Hasil-hasil penelitian menyebutkan bahwa setelah penebangan terjadi kenaikan aliran sungai dengan kisaran angka yang bervariasi mulai dari kisaran $20 \%$ sampai $100 \%$ (Waterloo et al., 2007; Sørensen et al., 2009; Nobrega et al., 2010; Khanal \& Parajuli, 2013; Hlásny et al., 2015). Hilangnya vegetasi penutup di kawasan hutan dan diganti dengan tanaman yang baru, akan secara temporal menurunkan ET dan selanjutnya akan meningkatkan hasil air (Waterloo et al., 2007; Jassal et al., 2009; Hlásny et al., 2015). Peningkatan hasil air akibat penghilangan penutupan hutan tersebut terjadi secara proporsional mengikuti jumlah biomassa hutan yang hilang (Hubbart, Link, Gravelle, \& Elliot, 2007; Sørensen et al., 2009; Zhao et al., 2009; Kuras et al., 2012; Khanal \& Parajuli, 2013).

Hasil penelitian di Perancis oleh Fritsch (1992) dalam (Waterloo et al., 2007), menyimpulkan adanya fenomena serupa pada konversi hutan hujan alam menjadi hutan tanaman $p$. caribaea dan E. grandifolia. Setahun setelah penebangan dan pembakaran (clearing and burning), peningkatan aliran sungai (storm flow) sampai lebih dari $80 \%$ (pada tanaman pinus) dan lebih dari $60 \%$ (pada tanaman ekaliptus) atau rata-rata 560-620 $\mathrm{mm}$. Hasil air tersebut kemudian menurun pada tahun ketiga setelah penanaman, masing-masing sebesar 30\% dan $10 \%$. Peningkatan penurunan yang terjadi lebih lambat pada kedua tanaman tersebut dibanding- kan pada penebangan yang diikuti permudaan alami. Hasil air baru mencapai kestabilan ketika tanaman sudah berumur 4 tahun.

Pada tanaman berumur kurang dari 1 tahun setelah penebangan merupakan fase-fase kritis bagi kondisi tata air, sebab sebagian besar permukaan tanah masih terbuka (Tian et al., 2008). Pada spesies tanaman Ekaliptus yang lain, disebutkan bahwa pengaruh tebang habis pada tanaman E. globulus di Spanyol telah meningkatkan hasil air tahunan sebanyak 73\%. Setelah ditanami permudaan dengan coppice system ratarata peningkatan hasil air sampai tahun ketiga sebesar $47 \%$ dan hilang pengaruhnya setelah tanaman memasuki tahun keempat Fernández, Vega, Gras \& Fonturbel, 2006).

Hasil penelitian juga memperlihatkan pengaruh penebangan terhadap hasil sedimen. Penebangan (tebang habis) telah menyebabkan peningkatan hasil sedimen rata-rata bulanan sebesar 8,9 kali (atau 788,7\%). Hal tersebut diperlihatkan oleh peningkatan hasil sedimen bulanan sebelum penebangan (rata-rata 0,18 ton per haper bulan) menjadi rata-rata 1,57 ton per ha per bulan (setelah penebangan). Hasil sedimen bulanan setelah penebangan juga terlihat lebih fluktuatif dipengaruhi oleh curah hujan (Gambar 4 dan Gambar 5). Hal tersebut menunjukkan adanya peran komunitas hutan (tanaman) dalam mengendalikan laju erosi dan sedimentasi yang terjadi (Ilvesniemi et al., 2010; Mohammad \& Adam, 2010; Hlásny et al., 2015; Pötzelsberger \& Hasenauer, 2015). 


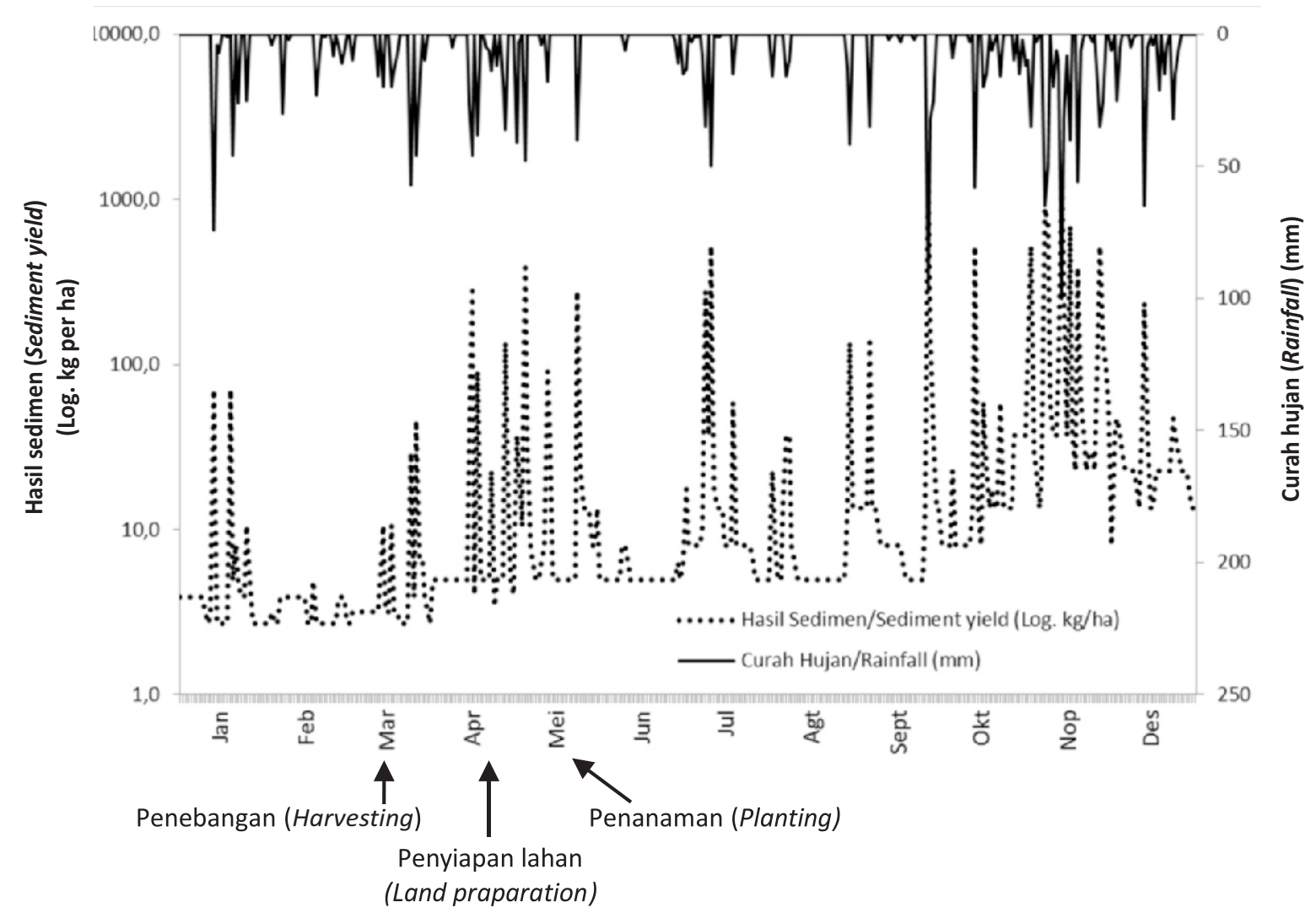

Gambar(Figure) 4. Grafik hujan dan hasil sedimen harian tahun 2012 (Graph of daily rainfall and sediment yield for year 2012)

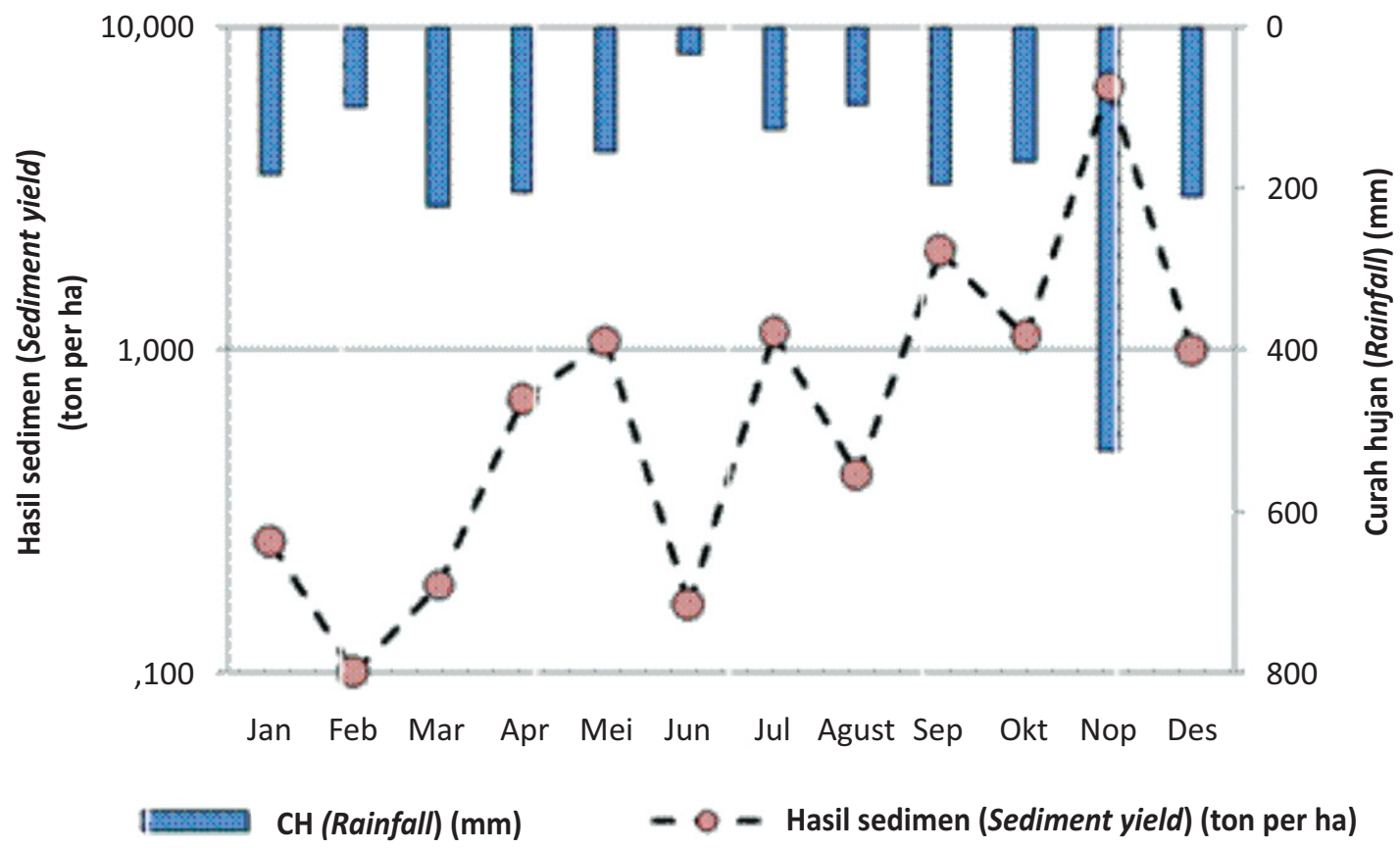

Gambar(Figure) 5. Grafik hasil sedimen bulanan tahun 2012 (Graph of monthly sediment yield for year 2012) 
Hasil penelitian ini juga selaras dengan hasil-hasil penelitian yang dilakukan sebelumnya. Scott \& Mount (2004) menyimpulkan bahwa hasil sedimen sebelum penebangan menunjukkan angka 55 ton per $\mathrm{km}^{2}$ per tahun, pada saat penebangan 89 ton per $\mathrm{km}^{2}$ per tahun (naik 61,8\%) dan setelah penebangan menjadi 98 ton per $\mathrm{km}^{2}$ per tahun (naik 78,2\%). Khanal \& Parajuli (2013) menyebutkan angka yang lebih besar, yaitu setelah penebangan seluas $10-75 \%$ dari luas area akan meningkatkan hasil sedimen 33- 250\%. Waterloo et al. (2007) juga menyebutkan dari hasil penelitiannya bahwa akibat penebangan tanaman Pinus caribaea di Fiji secara signifikan meningkatkan konsentrasi sedimen selama kejadian hujan atau banjir, tetapi tidak signifikan pada kondisi baseflow.

Sumber sedimentasi di dalam DAS secara umum sangat banyak. Di dalam DAS berhutan, sumber sedimen paling banyak terjadi akibat erosi tebing sungai (river bank erosion), tanah longsor (land slips) dan lahan terbuka pasca tebangan (Bruijnzeel, 2004; Gomi, Moore, \& Hassan, 2005; Brown, 2010; Cao et al., 2015). Hal serupa yang terjadi di lokasi penelitian hutan tanaman E. pellita di Riau. Setelah penebangan dilakukan dengan sistem tebang habis, praktis tidak ada lagi vegetasi pohon penutup tanah. Bahkan, sesuai dengan prosedur yang ada di perusahaan, setelah penebangan kemudian dilakukan pembersihan lahan dari semak belukar dalam rangka penyiapan lahan untuk penanaman rotasi berikutnya. Hal tersebut membuat kondisi tanah tidak terlindungi dari energi kinetis air hujan yang berpotensi menimbulkan erosi percikan dan erosi permukaan sebagai sumber sedimentasi. Pada fase inilah terjadi kontribusi sebagai sumber erosi sedimentasi yang paling besar, dibandingkan pada lahan ketika terdapat komunitas hutan tanaman (sebelum penebangan) (Scott \& Mount, 2004; Tian et al., 2008).

\section{KESIMPULAN DAN SARAN}

Akibat penebangan dengan sistem tebang habis di hutan tanaman E. pellita umur 6 tahun, telah menyebabkan perubahan pada karakteristik aliran sungai serta hasil sedimen Penebangan telah menyebabkan peningkatan aliran sungai sebesar $142,6 \%$ pada periode 0 sampai 8 bulan setelah penebangan serta peningkatan koefisien limpasan permukaan bulanan sebesar 95,3\%, yakni dari rata-rata $34 \%$ menjadi rata-rata $66 \%$. Penebangan juga telah menyebabkan pening- katan hasil sedimen rata-rata bulanan sebesar 9 kali yaitu dari rata-rata 0,18 ton per ha per bulan menjadi rata-rata 1,57 ton per ha per bulan.

Berdasarkan hasil penelitian, disarankan adanya upaya aplikasi konservasi tanah dan air terutama pada saat pasca penebangan dan saat tanaman muda. Upaya dapat dilakukan antara lain dengan penanaman tanaman penutup tanah (legume cover crops), penggunaan mulsa serasah bekas tebangan sebagai penutup tanah serta pembuatan teras pada lahan dengan kemiringan lereng di atas $40 \%$.

\section{UCAPAN TERIMA KASIH}

Penulis menyampaikan terima kasih yang sedalam-dalamnya kepada institusi Balai Penelitian dan Pengembangan Teknologi Pengelolaan DAS (BPPTPDAS) Solo atas dukungan penganggaran penelitian, Bpk. Kosasih (teknisi litkayasa) dan tenaga pendamping dari PT. Arara Abadi-Perawang Riau (Bpk. Betrizal Afni) atas segala bantuan selama kegiatan penelitian di lapangan.

\section{DAFTAR PUSTAKA}

Alidoust, M., Zahedi, S. S., \& Pornasrollah, M. (2012). Iran the role of plant cover (forest) in decreasing run off in North of Iran (Polrud basin). Int. J. Forest, Soil and Erosion, 2(4), 163-164.

Brown, K. (2010). Harvesting impact on streamflow and sediment loading in low gradient headwaters of the Gulf Coastal Plain. Louisiana State University.

Bruijnzeel, L. A. (2004). Hydrologycal functions of tropical forests: not seeing the soil for the trees? Agriculture, Ecosystems and Environment, 104, 185-228.

Cao, L., Liang, Y., Wang, Y., \& Lu, H. (2015). Run off and soil loss from Pinus massoniana forest in southern China after simulated rainfall. CATENA, 129 (Jun2015), 1 -8. doi:10.1016/j.catena.2015.02.009.

Feller, M. C. (2005). Forest harvesting and streamwater inorganic chemistry in western North America: a review. Journal of the American Water Resources Association, 41(4), 785811 . doi: $10.1111 / \mathrm{j} .1752$ 1688.2005.tb03771.x

Fernández, C., Vega, J. A., Gras, J. M., \& Fonturbel, T. (2006). Changes in water yield after a sequence 
of perturbations and forest management practices in an Eucalyptus globules Labill. Watershed in Northern Spain. Forest Ecology and Management, 234, 275-281.

Fukuyama, T., Onda, Y., Gomi, T., Yamamoto, K., Kondo, N., Miyata, S.,.... Tsubonuma, N. (2010). Quantifying the impact of forest management practice on the runoff of the surface-derived suspended sediment using fallout radionuclides. Hydrological Processes, 24(5), 596607. doi:10.1002/hyp.7554.

Gomi, T., Moore, R. D., \& Hassan, M. A. (2005). Suspended sediment dynamics in small forest streams of the Pacific Northwest. Journal of the American Water Resources Association, 41(4), 877898. doi:10.1111/j.17521688.2005.tb03775.x

Hidayat, Y., Sinukaban, N., Pawitan, H., \& Tarigan, S. (2008). Dampak perambahan hutan terhadap aliran permukaan dan erosi di DAS Nopu Hulu, Sulawesi Tengah. J. Tanah Trop, 13(1), 59-65.

Hlásny, T., Kočický, D., Maretta, M., Sitková, Z., Barka, I., Konôpka, M., \& Hlavatá, H. (2015). Effect of deforestation on watershed water balance: hydrological modelling-based approach. Forestry Journal, 61(2), 89-100. doi:10.1515/forj-2015-0017.

Hofer, T. (2003). Sustainable use and management of fresh water resources: the role of forest. State of the wordls forest 2003, part II: selected current issues in the forest sector. FAO Forestry Department.

Hubbart, J., Link, T., Gravelle, J., \& Elliot, W. (2007). Timber harvest impacts on water yield in the continental/maritime hydroclimatic region of the United States. Forest Science, 53(2), 169180 .

Ilvesniemi, H., Pumpanen, J., Duursma, R., Hari, P., Keronen, P., Kolari, P., ... Vesala, T. (2010). Water balance of a boreal Scots pine forest. Boreal Environment Research, 15(August), 375-396.

Jassal, R. S., Black, T. A., Spittlehouse, D. L., Brümmer, C., \& Nesic, Z. (2009). Evapotranspiration and water use efficiency in different-aged Pacific Northwest Douglas-fir stands. Agricultural \& Forest Meteorology, $149(6 / 7), \quad 1168-1178$. doi:10.1016/j.agrformet.2009.02.004.

Khanal, S., \& Parajuli, P. B. (2013). Evaluating the impacts of forest clear cutting on water and sediment yields using SWAT in Mississippi. Journal of Water Resource and Protection, 05 ( 04 ), $474-483$. doi:10.4236/jwarp.2013.54047.
Kuras, P. K., Alila, Y., \& Weiler, M. (2012). Forest harvesting effects on the magnitude and frequency of peak flows can increase with return period. Water Resources Research, 48(1), 1-20. doi:10.1029/2011WR010705.

Löfgren, S., Ring, E., von Brömssen, C., Sørensen, R., \& Högbom, L. (2009). Short term effects of clear-cutting on the water chemistry of two boreal streams in northern Sweden: a paired catchment study. Ambio, 38(7), 347-356. doi:10.1579/0044-7447-38.7.347.

Mohammad,A. G., \& Adam, M.A. (2010). The impact of vegetative cover type on runoff and soil erosion under different land uses. CATENA, 81 (2), $97-103$. doi:10.1016/ j.catena.2010.01.008.

Neris, J., Tejedor, M., Rodríguez, M., Fuentes, J., \& Jiménez, C. (2013). Effect of forest floor characteristics on water repellency, infiltration, run off and soil loss in Andisols of Tenerife (Canary Islands, Spain). CATENA, 108(Sep2013), 50-57. doi:10.1016/ j.catena.2012.04.011.

Nobrega, R., Souza, E., \& Souza, F. (2010). The impact of changes in land cover on water resources in the Western Amazon. Journal of Environmental Hydrology, 18(Oktober), 1-16.

Palmer, A. R. (2011). Natural variation and short-term impact of Aspen Harvesting on surface stream chemistry in the Boreal Plains (p. 112). Thesis of Master of Science, Department of Biological Sciences. The University of Alberta.

Pötzelsberger, E., \& Hasenauer, H. (2015). Forestwater dynamics within a mountainous catchment in Austria. Natual Hazards, 77(2), 625-644. doi:10.1007/s11069-015-1609-x.

Shamsuddin, S. A., Yusop, Z., \& Noguchi, S. (2014). Influence of plantation establishment on discharge characteristics in a small catchment of tropical forest. International Journal of Forestry Research, 2014, 1-10. doi:10.1155/ 2014/408409.

Sørensen, R., Eva, R., Marcus, M., Lars, H., Jan, S., Thomas, G., ... Bishop, K. (2009). Forest harvest increases run off most during low flows in two boreal streams. Ambio, 38(7), 357-363.

Stott, T. A., \& Mount, N. (2004). Plantation forestry impacts on sediment yields and downstream channel dynamics in the $\{\mathrm{UK}\}$ : a review. Progress in Physical Geography, 28(2), $197-$ 240. doi:10.1191/0309133304pp410ra.

Suárez, J., Soto, B., Perez, R., \& Fierros, F. (2011). Influence of Eucalyptus globulus plantation growth on water table levels and low flows in a small catchment. Journal of Hydrology, 396, 321-326. 
Suharta, N., \& Prasetyo, B. H. (2008). Susunan mineral dan sifat fisika kimia tanah bervegetasi hutan dari batuan sedimen masam di Propinsi Riau. Jurnal Tanah dan Iklim, 28(Desember), $1-14$.

Supangat, A. B. (2013). Keseimbangan air dan hara di hutan tanaman Eucalyptus pellita F. Muell melalui pendekatan model dinamik. Disertasi. Program Studi Ilmu Kehutanan, Fakultas Kehutanan. Universitas Gadjah Mada, Yogyakarta.

Supangat, A. B., Junaedi, A., Kosasih, \& Irwan. (2010). Kajian dampak penanaman jenis penghasil kayu pulp terhadap tata dan kualitas air. Laporan Hasil Penelitian. Balai Penelitian Hutan Penghasil Serat. Badan Litbang Kehutanan. Kuok, Riau. (tidak dipublikasikan).

Supangat, A. B., Junaedi, A., Kosasih, \& Nasrun. (2008). Kajian tata air hutan Acacia mangium dan Eucalyptus pellita. Laporan Hasil Penelitian. Balai Penelitian Hutan Penghasil Serat. Badan Litbang Kehutanan. Kuok, Riau. (tidak dipublikasikan).

Suryatmojo, H., Masamitsu, F., Kosugi, K., \& Mizuyama, T. (2013). Effects of selective logging methods on run off characteristics in paired small headwater catchment. Procedia Environmental Sciences, 17, 221-229. doi:10.1016/j.proenv.2013.02.032.
Tian, D., Yan, W., Chen, X., Deng, X., Peng, Y., Kang, W., \& Peng, C. (2008). Variation in run off with age of Chinese fir plantations in Central South China. Hydrological Processes, 22(25), 48704876. doi:10. 1002/hyp.7105.

Waterloo, M. J., Schellekens, J., Bruijnzeel, L. A., \& Rawaqa, T. T. (2007). Changes in catchment runoff after harvesting and burning of a Pinus caribaea plantation in VitiLevu, Fiji. Forest Ecology \& Management, 251(1/2), 31-44. doi:10.1016/j.foreco.2007.06.050.

Wenjie, L., Wenyao, L., Hongjian, L., Wenping, D., \& Hongmei, L. (2011). Run off generation in small catchments under a native rain forest and a rubber plantation in Xishuangbanna, southwestern China. Water and Environmental Journal, 25(1), 138147. doi:10.1111/j.17476593.2009.00211.x

Zegree, N. (2011). Evaluating the hydrologic effects of forest harvesting and regrowth using a simple rainfall-run off model. Journal of Environmental Hydrology, 19(11), 116. Retrieved from http://www.hydroweb.com

Zhao, F., Zhang, L., \& Xu, Z. (2009). Effects of vegetation cover change on streamflow at a range of spatial scales. 18th World IMACS/ MODSIM Congress, Cairns, Australia 13-17 July 2009, 35913597. Retrieved from http:// mssanz.org.au/modsim09/I8/zhao_ff.pdf 